\title{
The Great Divide and Beyond: Financial Architecture in Transition
}

\author{
By: Erik Berglof and Patrick Bolton
}

William Davidson Working Paper Number 414

December 2001 
The Great Divide and Beyond: Financial Architecture in Transition

Erik Berglof and Patrick Bolton

Forthcoming in: The Journal of Economic Perspectives

Erik Berglof is Director, Stockholm Institute of Transition Economics (SITE), Stockholm School of Economics, Stockholm, Sweden. Patrick Bolton is Professor of Economics, Princeton University, Princeton, New Jersey, and Research Associate, National Bureau of Economic Research, Cambridge, Massachusetts. Both authors are Research Fellows, Center for Economic Policy Research, London, United Kingdom. 


\section{William Davidson Institute Working Paper 414}

A growing and deepening divide has opened up between transition countries where economic development has taken off and those caught in a vicious cycle of institutional backwardness and macroeconomic instability. This "Great Divide" is visible in almost every measure of economic performance: GDP growth, investment, government finances, growth in inequality, general institutional infrastructure, and increasingly in measures of financial development. Strategies for financial development have differed dramatically across countries and over time, offering interesting opportunities to study the links between real and financial sector development.

Even in the countries that have made it across the divide like The Czech Republic, Hungary, Poland, Slovenia, and the Baltic states of Estonia, Latvia and Lithuania, a remarkable diversity of policies for financial development has been pursued. Yet, strikingly, today the basic financial architectures of these frontrunners are remarkably similar. These financial systems are strongly dominated by commercial banks, increasingly foreign owned, which lend primarily to government. Stock markets are highly volatile and illiquid, and their sustainability is in question as the numbers of listed firms are stagnating or even falling. Enterprises rely primarily on internally generated funds, and the bulk of external long-term finance comes from foreign direct investment. 


\section{William Davidson Institute Working Paper 414}

The Great Divide in economic and financial development and the convergence in financial architecture among the successful countries raise fundamental questions about how financial development interacts with economic growth. Is it possible to engineer a development take-off by creating a modern financial architecture from scratch? Or are financial institutions and markets a reflection of underlying conditions in the real sector? Or are both financial development and economic growth driven by some other underlying variables? Is it possible to leapfrog certain stages of financial development or must all countries go through a phase of bank-oriented financial architecture? The experience of the transition economies represents a unique opportunity to shed new light on these issues.

We start by describing the salient features of financial transition. We will argue that financial development does not explain why a small group of countries developed and grew while the majority of transition economies remained mired in economic stagnation. In general, the financial sector has played a small role in the restructuring of the manufacturing sector in transition economies, and in some cases financial liberalization may have undermined real sector development. We argue that the ability of governments of transition economies to achieve fiscal and monetary responsibility, together with a commitment to refrain from excessively bailing out failing banks or loss-making enterprises, determined whether economic and financial development 


\section{William Davidson Institute Working Paper 414}

took off. Fiscal responsibility promotes both financial development and economic growth through two important channels: it limits the extent of crowding out of private investment by government borrowing and it makes it credible that the government will be able to maintain the macro stability that is essential for private investment. In addition, it provides some guarantees that the returns from investment are not going to be taxed away in the future by excessively profligate governments desperately seeking tax revenues where they can find them. of course, specific initial conditions and underlying country characteristics facilitate the emergence of fiscally sound governments capable of enforcing the rule of law. We discuss what these conditions might be.

The Evolution of Banking and the Emergence of the Great Divide

All banking systems in transition economies have evolved from a single institution, the monobank, which was responsible for both monetary policy and commercial banking. In the monobank system, the overall level of credit was often quite high, with the aim of spurring production along the lines desired by the economic planners, rather than having loans channeled according to conventional standards of creditworthiness. The monobank was thus not a bank in the sense that it screened and monitored projects or enforced repayment of loans, rather it was the channel for funds allocated by the plan. Since the planned economy repressed or hid 


\section{William Davidson Institute Working Paper 414}

inflation with price ceilings and guaranteed jobs for all, at least nominally, the standard counter cyclical tasks of central banking were not especially relevant to the monobank.

The financial sector transition from a planned economy to a market-oriented economy involved transforming the monobank into a decentralized financial system integrated into a market economy. Most Soviet-bloc countries started this process by implementing more or less the same measures: by separating the central and commercial banking activities of the monobank and by breaking up the commercial banking activities into multiple smaller units. Most countries also allowed for entry of new banks.

In parallel, other important reforms were implemented, in particular price liberalization. A few countries got a head start in separating out these two functions and creating a two-tier banking system. The first was Yugoslavia during the 1960s. In the mid-1980s a few other socialist economies followed, Hungary in a more controlled way than the Soviet Union and Poland (Sgard, 1996) .

The separation of central and commercial banking brought with it some rudiments of monetary policy, like credit ceilings and refinancing windows. However, central banks had weak incentives to conduct price-stabilizing monetary policy and relatively little power to regulate the commercial banks. Central banks generally attracted highly talented people, but they were often politically weak. The extent of their independence from political influence varied greatly, and actual independence was often less than 


\section{William Davidson Institute Working Paper 414}

suggested by formal rules. Moreover, independence from the government did not alwaygp protect against influence activities by other lobbying interests. ${ }^{1}$

The new commercial banks formed from the break-up of the monobank faced difficult prospects. For a time, they were little more than an accounting construction and were run by segments of the old bureaucratic network and staff. Their inherited balance sheets included household deposits, loans from the central bank, and a portfolio of enterprise credits of unknown quality. Bank managers had little genuine banking experience, a generally low quality of assets, and little guidance from the poorly developed system of bank regulation. In addition, most of the newly created banks remained under state ownership and their business clients had yet to be privatized, so lending policies were not based on any financial or economic logic. Instead, non-performing loans losses were automatically rolled over, often with additional loans provided by the central bank (that is, by printing money). As a number of analysts had expected, lax lending practices to stateowned industry became an important source of inflationary pressure during the early phase of transition.

1 An interesting anomaly is the Central Bank of Russia which has far-reaching independence, but where the governor is also a cabinet member. For much of the 1990's Viktor Gerashenko, originally the head of the monobank Gosbank, occupied this position. During his first tenure under the Yeltsin presidency he systematically undermined the government's attempt to stabilize the economy by increasing the money supply to bail out ailing banks and firms. In his second tenure after the crisis of 1998 he has pursued a more strict monetary policy, but he also gave in to intense lobbying not to liquidate and restructure the defunct banking sector. 


\section{William Davidson Institute Working Paper 414}

These fledgling commercial banks were also operating in a difficult macroeconomic situation. Most Eastern European economies inherited a massive "monetary overhang": that is, household savings in deposit accounts that had accumulated as a result of the pervasive shortages of consumption goods and distortionary price controls under central planning. Following price liberalization, this money flowed into the economy and the monetary overhang turned into open inflation. Firms responded to this accelerating inflation with widespread hoarding of goods and by increasingly relying on barter arrangements, even among large businesses. Thus, just at the time when money and credit should have become more central to economic organization and transactions, the new banks found themselves in a macroeconomic environment where rapid disintermediation was occurring.

The first test of the institutional strength of this new constellation of commercial banks came in the early 1990s when central banks made an attempt to control monetary growth, which sharply reduced real credit and created a severe credit crunch (Calvo and Coricelli, 1995). In all transition countries, the initial response to the monetary tightening by enterprises was inertia; they reacted to the lower level of credit with mounting unpaid bills to suppliers and in some cases to workers. Some countries, however - mostly in central Europe and in the Baltic states - gradually managed to resist the pressures to bail out banks and enterprises. After the initial pain of the credit crunch and several banking crises, the eventual outcome in these 


\section{William Davidson Institute Working Paper 414}

countries was a stable monetary and fiscal policy. Some of these countries, e.g. Estonia, went as far as locking in monetary stability through a currency board arrangement. This in turn laid the foundation for a virtuous spiral of microeconomic restructuring and macroeconomic consolidation. These countries managed to gradually re-orient their productive sector and integrate it with world trade, thus restarting the growth process early on.

In other transition countries, including most of the former Soviet Union as well as countries in southeast Europe, like Bulgaria and Romania, authorities did not, or could not, resist the pressures for financial relief. Central banks, after only a few months of attempted stabilization, provided additional loans to commercial banks and monetized the rapidly increasing stocks of credit. This pattern of repeated bailouts for both banks and businesses led to a lack of enterprise restructuring, $\square^{\text {weaker }}$ banks, and the need for more inflationary credit bail-outs ${ }^{2}$. As a result these countries have experienced a much more protracted slump than might otherwise have been the case. The Great Divide had opened up.

Measuring Financial Development

2 A recent positive development which goes against this sharp characterization is the adoption of a currency board by Bulgaria which has provided some welcome monetary stability. 


\section{William Davidson Institute Working Paper 414}

Data limitations are a serious constraint for analyzing the interaction between economic and financial development in transition economies. Standard measures of financial development include the assets of financial institutions, the amount of money in circulation, and loans to households and enterprises. However, in the early phases of economic transition GDP statistics are of dubious quality. The very high levels of inflation during this period in most countries resulted in large nominal GDP figures and measures of credit as a share of GDP do not adequately correct for inflation in the early years as initial credit measures were mainly accounting fictions, which did not reflect inflationary expectations. In addition, above average lending flows to enterprises may have been a symptom of weakness, or softness, rather than a reflection of above average financial development. 目

With these cautions duly noted, Table 1 shows the development of domestic credit to the private sector as a share of GDP during the period 1994-1999 (unfortunately, data for the earlier years of transition is only available in a few countries). Taking this measure at face value, only Estonia, Poland, Slovakia and Slovenia saw relatively steady expansion of credit. These countries are also grouped as having crossed the Great Divide, but they are not alone in having done so. The Czech Republic had very high levels

3 Another issue of mismeasurement arises with privatizations. Table 2 typically excludes state-owned enterprises, so that privatization of firms with bank credits is registered as financial development even though nothing has actually changed in terms of the amount of credit extended. 


\section{William Davidson Institute Working Paper 414}

of credit already, which reflect the mass privatization of enterprises and extensive bad loans, and thus exaggerate its relative financial development. Hungary had four severe banking crises in four years during the first half of the 1990s resulting in a sharp drop in credit from 45 percent of GDP in 1990 to 24.7 in 1994. But since then its level of credit has expanded in step with economic growth. Similarly, Latvia and Lithuania first experienced banking crises in the mid-1990s which reduced the ratio of credit to GDP, followed by a recovery. It is important to stress that in all these countries the real impact of these financial crises was moderate. Most of the problems stemmed from bad stocks rather than flows, and banks had mainly been lending to government and less to households and enterprises. To summarize, the experience of financial transition in the most successful group of countries provides weak evidence at best of a link between financial development and growth.

The correlation between financial development and economic growth is even weaker in the other countries. Bulgaria experienced rapid growth in credit in the mid-1990s and then a drastic fall in the late 1990s, but its economy declined or showed moderate growth over this time period. In Russia, financial markets developed rapidly and credit to households and enterprises increased somewhat in the late 1990s, while the economy continued to

4 A footnote on the Baltic countries may be warranted here. These countries still have lower levels of economic wealth due to lower starting points and deeper and more protracted initial declines. But their institutional development has proceeded much faster than other CIS countries and on par with the lead reformers in 


\section{William Davidson Institute Working Paper 414}

stagnate. The financial crisis in August 1998 had little longterm impact on real growth. Some observers even argue that the crisis had a positive effect on economic development by cutting to size some of the interests blocking reform. While there was a slight fall in credit the economy subsequently grew rapidly. Ukraine, and many other countries that were formerly part of the Soviet Union, saw neither financial development nor economic growth. In sum, the link between financial development and economic growth does not appear to be very strong during the first decade of transition, at least when one looks at the ratio of domestic credit to GDP.

On the other hand the differences in development stand out more in measures of financial reform (EBRD, 2000) and general institutional quality such as "law on the books" and "law enforcement" indices (Pistor et al., 2000; and Kaufmann et al., 2000). While most of the transition countries have adopted increasingly sophisticated legal and regulatory frameworks in the financial area, implementation and enforcement is significantly better in countries on the right side of the divide. Table 2 gives an index of banking reforms, and Table 3 an index of reforms of non-banking financial institutions. All these measures of institutional quality inevitably involve a considerable degree of judgment and should be interpreted with care. Nevertheless, they do highlight the Great Divide; they have also been good predictors of vulnerability during the Asian crisis of 1997-1998 (Johnson et 


\section{William Davidson Institute Working Paper 414}

al., 2000). Obviously, the interesting underlying question is what explains these differences in institutional quality.

Beyond the Great Divide: Different Policies and Systemic Convergence of Financial Architecture

The transition experience does not reveal a single magic policy formula guaranteeing a successful path for financial and economic development. Among the countries that have failed to bridge the Great Divide, a variety of policies have been tried, and several varieties of dysfunctional financial systems have emerged. In Russia and the Ukraine, most commercial banks are in private hands, but most of these banks are insolvent and should be closed down. Financial institutions and markets in these two countries were severely hit by the financial crisis in 1998. Also, in these countries corruption, crime and cronyism undermine enforcement of the legal and regulatory framework. Also, political resistance towards further reforms remains strong. A second group of less successful transition countries, including Bulgaria, Romania and Slovakia have only made partial attempts to reform. The largest banks in these countries are still predominantly state-owned. In addition, the presence of a large number of insolvent banks undermines competition. While the regulatory environment is improving enforcement remains weak.

In the more successful countries in Central and Eastern Europe financial architecture is converging despite major differences in 


\section{William Davidson Institute Working Paper 414}

policies pursued. After an early boost in stock market activity in the aftermath of mass privatization and different policy responses to the banking crises following price liberalization, bank-based financial systems are emerging. Some examples of these policy differences include: procedures for restructuring bad loans, privatization strategies for enterprises and banks, policy towards foreign entry in the banking sector, regulatory barriers to entry of new banks, and policies toward stock market development.

The approach to cleaning up bank balance sheets has also been very different across transition countries. Both the extent to which banks were induced to stop rolling over bad debts to enterprises and the methods used to recapitalize banks varied widely across transition countries. Some countries, like the Czech Republic, transferred bad debts to specialized "hospital" banks, while others, like Poland, chose to clean up balance sheets within existing institutions.

In an attempt to encourage banks to stop rolling over their bad debts and to deal with the growing problem of payment delays Hungary adopted a devastatingly effective bankruptcy law. It had an automatic trigger which more or less overnight forced much of Hungary's industry into court-led bankruptcy procedures. The sheer number of cases paralyzed Hungary's courts. Mitchell (1993) characterized it as a "too many to fail" situation. Inevitably Hungary had to quickly water down its new bankruptcy law and remove the automatic trigger. In a similar attempt the Czech Republic adopted a bankruptcy code just after its mass 


\section{William Davidson Institute Working Paper 414}

privatization program, but suspended its application for two years in response to political pressure from many unprofitable stateowned and privatized firms. Once the Czech bankruptcy law came into force it led to a wave of takeovers of smaller, not necessarily less efficient, firms by large politically connected firms. In a more pragmatic approach Poland opted for informal workouts outside courts under a moratorium on bankruptcy, with the government offering to give up the seniority of its tax claims to provide incentives for banks and firms to agree to restructure their bad loans.

Countries in transition also opted for very different strategies for privatizing state-owned enterprises. These differences are broad even if one focuses only on those countries that successfully crossed the Great Divide. For example, Hungary started privatization early and followed a case-by-case sales method, while the Czech Republic opted for a mass voucher privatization scheme. A small group of investment funds (tied to large banks) controlling most privatized assets emerged from this mass voucher privatization following the repurchase of most dispersed vouchers from households. Poland dragged its feet in implementing mass privatization, out of a concern that the legal and supervisory environment be strengthened first, but then proceeded with privatizing a number of individual firms through management buyouts and liquidation schemes.

Bank privatization also followed quite different paths. The Czech Republic included banks in the first wave of voucher 


\section{William Davidson Institute Working Paper 414}

privatization. Poland combined management buyouts, some public offerings and smaller placements with foreign strategic investors. Bank privatization accelerated across central Europe in the second half of the 1990s, but governments often retained strategic stakes. Despite these different privatization strategies, all of these countries ended up with similar bank-based financial systems a decade later. The countries on the "wrong" side of the Great Divide generally have higher shares of banking assets controlled by the state (the Ukraine being an exception).

It was not until foreign banks were allowed to acquire strategic stakes in the domestic banking sectors that private ownership took a firm hold in the banking sector of most countries. By now, several countries have high foreign ownership shares. Hungary was the first country to allow widespread foreign penetration in the banking sector. Foreigners now control more than 40 percent of shares in Hungarian banks, accounting for as much as 80 percent of assets (Abel and Bonin, 2001). The Baltic states of Estonia, Latvia, and Lithuania also have very high shares of foreign ownership, primarily from banks based in Scandinavian countries. Poland initially took a positive stance towards foreign ownership of banks, then backtracked, before opening the banking sector again to foreign ownership. The czech government was initially resistant to foreign ownership of banks, but several large bank failures finally opened up ownership to foreign institutions. Today the shares of foreign ownership of banks in Poland and the Czech Republic are 52.8 and 50.7 percent, respectively. In the 


\section{William Davidson Institute Working Paper 414}

countries on the "wrong" side of the Great Divide the presence of foreign banks, as well as other foreign direct investment is much more limited partly by design and partly by default. Understandably, foreign banks have been reluctant to buy stakes in weak institutions.

Most transition countries experienced significant entry of new banks following financial liberalization and the separation of monetary policy and commercial banking (Tang, 1999). In the Baltic states and in Russia the number of registered banks increased dramatically in the early years of transition. This wave of new entrants imposed a heavy supervisory burden on central banks with little experience in the task. Most new entrants were small and closely tied to newly privatized enterprises. Most of them quickly became insolvent. Some countries, in particular Romania and Albania but also Russia, even witnessed devastating episodes of frenzied speculation around a small number of unscrupulous banks, which started unsustainable pyramid or Ponzi schemes drawing in thousands of inexperienced and gullible households. The inevitable failure of these banks led to severe financial crises and seriously undermined confidence in banking institutions in these countries.

In contrast, in countries of central and eastern Europe new bank entry has been on a much smaller scale. There has been a moderate increase in the number of banks in Hungary. The number of banks rose somewhat, then fell again in the Czech Republic, declined slightly in Poland, and fell sharply in Bulgaria. The number of 


\section{William Davidson Institute Working Paper 414}

banks has shrunk following several banking crises and more consolidation is underway. Foreign-owned banks and banks with stronger capital-asset ratios are growing more rapidly than other banks. On the other hand larger, more dominant institutions are expanding more slowly (Fries and Taci, 2001). Privatized and new private banks have grown at about the same rate as state-owned banks. On the whole, however, the growth of bank loans has not kept pace with real sector growth.

Table 4 provides some data on the banking industry and the official numbers of bad loans, including countries on both sides of the Great Divide. The first column highlights that despite new entry the banking sector is heavily dominated by the three largest banks in most countries. These banks are not only able to exert monopoly power in deposit and lending activities, but also often yield considerable political influence. The fourth column shows the worst performers in terms of cleaning up bank balance sheets. The Czech Republic, Romania and Slovakia had a bad-loans-to-totalloans ratio between 30 and $40 \%$ in 1999. This compares with a reported ffatio of 7.8 for Italy, 1.4 for Japan and 0.7 for the US in 1998.5 The fifth column gives figures for bank spreads. The lower the spread the better is the banking sector and the legal protection of creditors, other things equal. Indeed, high spreads

5 Anyone vaguely familiar with the current situation in the Japanese banking system may question the reliability of these numbers. The uncertainty should be even greater in the countries of Central and Eastern Europe, in particular in the countries on the "wrong" side of the Great Divide where regulatory powers are weaker and the incentives to hide bad loans stronger. 


\section{William Davidson Institute Working Paper 414}

reflect higher banking costs, greater monopoly power and greater lending risks.

As hinted at before, many countries pursued a policy of stock market development in the early stages of transition (Claessens, Djankov and Klingebiel, 2000). One group of countries -- including the Czech and Slovak Republics, Lithuania and Romania -- made heavy use of stock markets to transfer ownership through mass privatization. The number of firms listed on these stock exchanges increased dramatically, but after an initial phase of high trade volumes, most stocks became and remained illiquid. Over time, many companies have been delisted, and the number of shareholders fell as ownership became increasingly concentrated. Table 5 shows the pattern of flat or declining numbers of companies listed on stock markets in a selection of transition economies. Regulation of stock exchanges was minimal. In the Czech Republic, a formal regulator was not even established.

A second group of countries - including Estonia, Hungary, Latvia, Poland and Slovenia - developed their stock exchanges mainly through a small number of initial public offerings. Trading in most of these shares remained relatively high. A third group of countries that were formerly part of the Soviet Union, including Russia and the Ukraine, developed stock markets through both privatization and initial public offerings. All these countries had mass privatizations, but the exchange of vouchers took place outside the official stock markets. Six transition countries Albania, Belarus, Bosnia-Herzegovina, Georgia, Tajikistan, and 


\section{William Davidson Institute Working Paper 414}

Turkmenistan - never established stock markets.

Despite these marked differences in policies with regard to financial architecture, it is a remarkable fact that the financial systems in the more advanced transition countries have converged and now share three key features.

First, the financial sector of the successful transition economies is strongly dominated by banks, which lend primarily to governments and other financial institutions. Banks provide some working capital finance to the corporate sector, but so far have played a limited role in financing investments. Investment finance comes almost exclusively from retained earnings, and most external finance comes through foreign direct investment (IMF, 2000).

Second, ownership structures in individual firms are concentrated and turnover of shares is low. Only the stock markets in Czech Republic, Estonia, Poland and Hungary have capitalization-to-GDP ratios comparable to other emerging markets (23, 37, 36, and 20 per cent, respectively). But most exchanges are very illiquid with trade concentrated in a small number of firms (Claessens, Djankov and Klingebiel, 2000). The number of listed firms has decreased as a result of foreign acquisitions, domestic mergers and delisting. The best firms show limited interest in listing on local exchanges, preferring instead the quality stamp and liquidity of the international stock markets in Europe and the United States. At the end of 1999, 72 corporations from transition economies were listed on the New York Stock Exchange or Nasdaq, and companies listed in Germany accounted for 


\section{William Davidson Institute Working Paper 414}

most of domestic market capitalization in Hungary and the Czech Republic. Turnover is, however, still mostly concentrated to local exchanges. The long-term sustainability of some of these exchanges are nevertheless in doubt, given the growing integration of financial markets in Europe and the world.

Third, bank spreads -- that is, the difference between lending and borrowing rates --have declined significantly in level and volatility in most countries of central and eastern Eureope. Nevertheless they remain high by the standards of developed market economies (see Table 4); corresponding levels for the US and Sweden in 1999 were 2.7 and 3.9 per cent, respectively.

To summarize, the countries that find themselves on the prospering side of the Great Divide have now established the basic structure of their financial systems. They all have converged to mainly bank-based financial systems, with a significant fraction of foreign bank ownership. Local equity markets have gradually declined and have been overshadowed by European or U.S. stock exchanges. Important vulnerabilities, however, remain and some of the countries still require major, potentially difficult, reforms. The countries on the "wrong" side of the Great Divide also have financial systems dominated by banks, but the portfolios of these institutions are in a much worse state and the regulatory environment significantly weaker. As a result, budget constraints of banks and ultimately of governments are more likely to be soft.

Stock markets are even less developed. Much of the difficult work of financial development still remains, and most of these 


\section{William Davidson Institute Working Paper 414}

countries will only have limited help from the accession process to the European Union, the process that has been so important for the front-runners in Central and Eastern Europe.

Financial Transition and Financial Development: Different Starting Points and Moving Targets

Transition is a unique historical event and there are limits to the generality of the lessons that can be drawn from the experience for financial development. As the preceding brief overview of a decade of financial transition highlights, these countries started out with fundamentally imbalanced financial systems supported by powerful institutions. It was inevitable that any development would have to be preceded by an elimination of the monetary overhang and a protracted institutional breakdown. In some cases this breakdown is not yet complete, whereas in others old institutions effectively lost their role within a few years. On the other hand, many developing countries also have grossly distorted financial systems often with extensive state intervention or "crony captalism" requiring wide-ranging institutional transformation. In the end the differences between the issues raised in the financial development literature and those of financial transition must be more a matter of degree than of qualitative distinctions.

In particular, the transition experience can shed new light on the difficult question of whether financial development can be 


\section{William Davidson Institute Working Paper 414}

engineered to create a financial infrastructure enhancing economic growth. Certainly initial hopes were high that a financial infrastructure could be created to help transition economies leapfrog stages of development. Partly these hopes were based on the first findings of the emerging financial development literature linking financial development to subsequent growth experience. From a technological point of view, some leapfrogging has taken place. For example, ATM machines are widely available in most countries in Central and Eastern Europe and in many CIS countries, and some front-runner countries have high penetration of internet banking. But when it comes to basic institutions of finance these hopes appear to have been unrealistic.

Financial Development and Economic Growth

A number of empirical studies based on cross-country regressions have found that financial development at any given point in time as measured by the ratio of bank lending to GDP, and/or the ratio of stock market turnover to GDP -- is positively correlated with future per capita economic growth (for example, King and Levine, 1993a, b; Levine and Zervos, 1998). The conclusion generally drawn from these studies is that "well-functioning financial intermediaries and markets promote long-run economic growth" (Beck, Demirguc-Kunt and Levine, 2001, p. 1). The implied prescription for transition economies is to focus on financial reform as one of the ways to achieve economic growth.

Another set of empirical studies have found a statistical 


\section{William Davidson Institute Working Paper 414}

relation between legal investor protection and financial development. These studies have used a country's legal origin as an instrument for resolving the vexing endogeneity question of the interaction between legal protection of investors and investment flows to the corporate sector. Legal origin is typically categorized according to common law vs. civil law traditions and/or English versus French, German or Scandinavian legal traditions. The theory is that common law traditions are more investor friendly and since legal tradition clearly predates investment flows to corporations following the industrial revolution a clear causal link can be established between the degree of investor protection and the size of outside investment funds to corporations. A common finding of these studies is that countries with a French legal tradition tend to be less financially developed (Laporta, Lopez-de-Silanes, Shleifer and Vishny 1997, 1998; Levine, 2000; Beck, Demirguc-Kunt and Levine, 2001).

The policy implications from these contributions are less clear as legal traditions are not easy to change. But the findings suggest a link between a country's legal infrastructure (specifically the degree of legal investor protections) and financial development. Indeed, looking beyond legal origin, these studies also find a direct positive relation between financial development and various indices of investor protection (LaPorta, Lopez-de-Silanes, Shleifer and Vishny 1997, 1998). Other studies find a positive relation between per capita income and various 


\section{William Davidson Institute Working Paper 414}

indices of investor protection (Levine 2000; Acemoglu, Johnson and Robinson, 2000). Most intriguingly, these studies also suggest that legal origin has persistent long-run effects on financial development.

A general difficulty in applying the literature on legal origin and financial development to transition economies is that there is little variation in legal origin, most countries having a civil law tradition. In addition, most countries have adopted civil-lawtype institutions in order to facilitate EU accession. One exception is Russia, which has had a brief but unfortunate experiment in a common law approach to corporate law.

More importantly, the view that legal origin has persistent effects on financial development, however, is difficult to reconcile with the observation of Rajan and Zingales (2000) that financial development in 1913 was significantly higher in France than in the United States -- apparently the French legal system was not holding back investment flows to corporations at that time. Rajan and Zingales also observe that around the world, financial development peaked before World War I, then declined until well after World War II, before growing back to a new peak at the turn of the twenty-first century. This financial history suggests that other important factors affect financial development besides legal origin and investor protection.

What might these factors be? Rajan and Zingales invoke the political power of incumbents. They propose that insiders, primarily incumbent managers or owners and labor unions, are 


\section{William Davidson Institute Working Paper 414}

inherently opposed to financial development, as it would bring about greater competition from new entrants. In times of crisis or conflict these insiders gain more political influence and are able to push through legislation protecting their interests and inhibiting the growth of financial markets. With greater prosperity, however, these interest groups lose their grip on political power, so that eventually new legislation is passed fostering the development of financial markets. Although this story could explain the U-shaped pattern of financial development of advanced economies in the twentieth century, a deeper analysis is clearly required before one can say with any confidence whether financial development is mainly driven by such a political struggle between insiders and outsiders. Also, Mancur Olson (1982) has convincingly argued in another context the opposite story that insiders become entrenched in good times, and recessions serve to break their hold on critical institutions. Why his story would not apply to financial development remains an open question.

Interestingly, insider control has also been singled out to be the key governance problem in transition. Privatization in most countries resulted in a transfer of control to incumbent management and in some cases to workers. While many firms were looted by their managers initially, they have later tried to find ways to commit not to expropriate investors. However, without effective bonding devices or mechanisms to transfer control to investors, firms have been confined to defensive cost-cutting measures and growth based on internally generated funds. 


\section{William Davidson Institute Working Paper 414}

Other factors relevant to transition that could also explain the observed pattern of financial development around the world are:

i) the stock-market crash in 1929, the ensuing banking crises and the general loss of confidence in financial markets and institutions, similar to the experience of many transition countries;

ii) the rise of the welfare state following the onset of the great depression and World War II, which has had the important effect of removing retirement savings from capital markets. It is only in the 1980s that contribution-based retirement plans have been introduced (mainly in the United States and the United Kingdom). These plans have had a major impact on the growth of the private pension fund industry and on the growth of securities markets in the last two decades. Similar if more limited reforms are also underway in some of the more advanced transition countries, and this should help financial sector development, in particular the growth of securities markets. It is, however, still an open question whether these commitments to privately funded schemes are credible in countries where large segments of the population may end up with very low retirement benefits;

iii) the growth of the public sector in response to the great depression, the war production effort and, nationalizations following World War II (in the UK, France and Italy). A larger public sector meant that a smaller fraction of corporate investments required funding from private sources, thus limiting the extent of the private sector. Again, it is only since the 


\section{William Davidson Institute Working Paper 414}

beginning of the 1980's that the public sector has been scaled back through large-scale privatization programs (Bortolotti, Fantini and Siniscalco, 2001): It is still an open question what size of public sector the transition countries will eventually aim for, but the choice couldhave important ramifications for financial development;

iv) the growth of government debt and the resulting rise in longterm interest rates, which have discouraged private investment. This factor is of particular importance for some transition economies, where extremely high yields on government bonds have discouraged bank lending to the private sector. One piece of evidence consistent with this view is the growth in private lending witnessed in Russia following the default on government bonds in 1998 (see for example, Huang, Marin and Xu, 2001).

Bank-based versus Financial Market-based Systems

Most developing economies have bank-based financial systems and financial markets play a relatively minor role. It is only at more advanced stages of development that one sees financial markets, including stock and bond markets, play an increasingly important role. Various explanations have been given for this pattern.

One influential view is that when accounting rules and, more generally, regulatory and contractual enforcement institutions are weak, banks are better placed to protect creditor rights (Gerschenkron, 1962; Rajan and Zingales, 1998). Small investors are deterred from investing in the stock market for fear of being 


\section{William Davidson Institute Working Paper 414}

exploited by unscrupulous stock price manipulators and insider traders. They feel that their savings are better protected in deposit or savings accounts at banks, which are generally subject to some form of supervision by the state.

On the corporate side, most firms are too small and risky at early stages of development to be able to issue shares or bonds on an organized exchange at a competitive cost of capital. Only the more advanced economies have a sufficient number of large and stable firms that could get cheaper funds by issuing securities and thus create the thick market externalities necessary to sustain efficient stock markets (Pagano, 1993). Stock markets also tend to develop when there is a culture of equity investment and private pension plans, over and above regulatory protections to limit price manipulation and fraud. Finally, stock markets require well-trained professionals, market makers, traders, fund managers, and financial regulators, none of which were present at the beginning of transition.

A casual look at financial architecture in developing countries suggests that as the real economy develops, there is a gradual shift from bank-based to market-based corporate finance, but the empirical literature exploring the link between bank-based or market-based financial systems and per capita growth produces mixed evidence. Several studies have found that greater financial intermediation is associated with greater future growth (King and Levine, 1993a, b) and that stock market development is also positively related with future growth (Levine and Zervos, 1998). 


\section{William Davidson Institute Working Paper 414}

More recently, Tadasse (2000) has refined these findings by highlighting that for the less financially developed countries a greater emphasis on financial intermediation is positively correlated with future growth, while for the more developed countries there is a negative correlation between financial intermediation and growth. On the other hand, Levine (2000) finds that the relative weight of bank versus market finance is not significantly related to economic growth in cross country regressions once legal protection is introduced as an additional factor.

The transition experience lends some support to the notion that bank-led finance may be inevitable at certain stages of development and that efforts to develop stock exchanges in some countries may have been premature. On the other hand the evidence of a link between bank-based development and economic growth is weak. As we have already highlighted the monetary, fiscal and regulatory environment under which financial institutions and markets had to operate appears to have been as or more important in facilitating both financial and economic development.

Financial Development, Inequality and Instability

While exploring the link between legal infrastructure, investor protection and aggregate investment, some researchers have argued that the legal infrastructure and the extent of investor protection are proxies of broader underlying country 


\section{William Davidson Institute Working Paper 414}

characteristics like wealth inequalities, political polarization and macro-instability. For example, Perotti (1996) found that the risk of expropriation of investors is related to political polarization and conflict, which itself is linked to wealth inequalities. Similarly, several empirical studies surveyed in Benabou (1996) have found that protection of property rights is weakened when there is greater income inequality and that greater political instability tends to decrease investment and growth. Also, in a study of financial development in Latin American countries, Padilla and Requejo (2000) have found that macroeconomic stability is a more important factor determining development of lending to the corporate sector than creditor protection.

A systematic analysis for transition countries exploring the link between property rights protection and underlying factors such as political polarization, wealth inequalities and macroinstability remains to be undertaken. However, consistent with the findings of Perotti (1996) and others is the dramatic rise in inequality and poverty rates witnessed by some countries on the wrong side of the great divide with particularly weak property rights enforcement like Russia, Romania and the Ukraine. Most transition countries started out with low income inequality as measured by the Gini coefficient, which was around 0.2 on average at the beginning of transition (cf. Sweden and United States at the time with 0.25 and 0.40 , respectively). All of the transition countries have subsequently seen income inequalities rise 


\section{William Davidson Institute Working Paper 414}

significantly. But the CIS countries experienced much more dramatic increases with Ukraine and Russia now having extremely skewed income distributions (see Figure 1).

Explaining the Great Divide and Systemic Convergence

The emergence of the Great Divide illustrates how difficult it is to implement sustainable financial development and how much underlying country characteristics matter. Indeed, the reason why some countries were able to cross the Great Divide while others did not must be sought to a large extent outside the financial and legal system per se.

As we have argued, one leading explanation for the observed variation in financial and economic development across transition countries can be found in the differences in fiscal and monetary discipline and the enforcement capacity of governments. Without fiscal and monetary discipline government borrowing crowds out or discourages investment in the private sector and increases macroeconomic uncertainty (for some recent evidence, see Fries and Taci, 2001).

As pertinent as this diagnosis may be it is not all that helpful if one does not also identify why some countries tend to have fiscally irresponsible governments but not others. What determines whether a government will be able to show fiscal and monetary restraint? To address this question we must return to the situation facing transition countries in the wake of transition, 


\section{William Davidson Institute Working Paper 414}

when the first step towards financial development had been taken by breaking up the monobank and ending central economic planning. One heritage of the Soviet past was that governments were locked into financial relationships with a large number of firms facing daunting restructuring tasks. The pressure to keep many lossmaking firms afloat through subsidies was tremendous.

One reason why some countries ended up on the wrong side of the Great Divide was that political and economic costs of resisting calls for bailouts were too great. To appreciate the challenge facing some of these countries, particularly those that were part of the Soviet Union, one must look back even further to the Soviet system of production (Berliner, 1976; Kornai, 1992). This system typically involved production on a very large scale, with in many cases only one firm producing or assembling a particular good. It was partly a political decision by Stalin and later Soviet leaders to make regions overspecialized and interdependent, and thus to increase the costs of separating a particular republic. In addition, the soviet economy had a disproportionately large military-industrial sector, where the choice of geographic location of a factory was often made for political reasons rather than comparative advantage. The legacy of these arrangements are visible in today's Russia in the many "one-factory-towns" and the large pppulation living in economically non-viable areas of the country ${ }^{6}$. Following the breakup of the Soviet Union, most newly

${ }^{6}$ In contrast, China relied much more on a strategy of regional decentralization; for an interesting comparison of Chinese and Russian planning see Qian and Xu (1993). 


\section{William Davidson Institute Working Paper 414}

independent states therefore inherited a highly concentrated and often also an economically nonviable industrial base, which they had little choice but to keep afloat at least in the short run.

Another factor that affected why some governments were able to impose fiscal and monetary discipline and others not is the coordination of enterprises' lobbying efforts for more subsidies and bailouts (Perotti, 1998). In many countries, more or less formalized groups of financial and industrial firms have formed, partly because they were previously connected to the same administrative structure. These groups made it easier for their members to extract benefits from government. Several studies in Russia have shown that such groups were able to relieve credit constraints of individual member firms (Perotti and Gelfer, 2001; Volchkova, 2000). But they may also have served the purpose of extracting inefficiently large resource transfers from the state.

On the other side of the budget equation, another important factor that has affected government fiscal and monetary discipline was its ability to raise taxes and other revenues. Several countries that have made it across the Great Divide have been able to raise significant revenues through privatization of state assets. But perhaps a more important common denominator of these countries is the considerable legitimacy of their new democratically elected governments. These countries have also had some experience with democracy before World War II and have generally a greater respect for "the rule of law". These factors 


\section{William Davidson Institute Working Paper 414}

are obviously of critical importance in limiting tax evasion and in facilitating the enforcement of existing rules and regulations. As Pistor et al. (2000) have pointed out, an important obstacle towards greater financial development is the lack of enforcement of existing laws, rather than the existence of an inadequate legal framework.

Conversely, for the countries on the wrong side of the Great Divide, one of the main handicaps inherited from the communist past has been the lack of legitimacy of the state combined with the lack of experience with democratic government. Within the countries that were formerly part of the Soviet Union, only the Baltic states have had a relatively recent experience with democracy. In central and eastern Europe, Bulgaria and Romania have had virtually no experience with democracy even if they did not live under communism for as long as the Soviet Union.

The ability of governments to implement fiscal and monetary restraint has also undoubtedly been influenced by the country's geographical proximity and likelihood of accession to the European Union. When countries are located close to markets with large and rich populations, the potential benefits from trade are greater and restructuring appears more attractive. Prior experience of trade with the west appears to be an important predictor of whether enterprise restructuring has been undertaken or not. Most of the growth in central and eastern Europe has come from new firms or firms with extensive trade links with the west during the communist era (Walsh and Duffy, 2000). 


\section{William Davidson Institute Working Paper 414}

The possibility of joining the European Union has also played an important political role in advancing the reform process in much of central and eastern Europe. The more certain and the sooner the possibility of joining the Union, the stronger has been the leverage of this outside anchor (Berglof and Roland, 2002).

These observations can go a long way towards explaining the emergence of "crony capitalism" in some of the transition countries as well as the lack of fiscal and monetary responsibility of their governments. They also provide a reasonably good fit for which countries made it across the Great Divide. On the other hand, these observations are less useful for understanding the differences in policies pursued among the group of countries that made it across the Great Divide, or the subsequent convergence in the systemic features of their financial architecture.

Financial Transition: When will it end?

The task of transforming centrally planned economies into wellfunctioning market economies appeared to be so simple to early reformers that several plans have been proposed in the early days to complete transition in less than 500 days! A decade or more into transition it is fair to say that even the frontrunners are far from having completed their financial transition. Even though the basic financial architecture of a market economy is now in place in the countries on the right side of the divide, banking and other financial institutions do not yet perform their intended 


\section{William Davidson Institute Working Paper 414}

functions of channeling savings to the most productive investments.

Another unexpected development of the past decade is that the financial system of advanced market economies itself has evolved rapidly. Reformers only belatedly realized that the transition process partly involves chasing a moving target. As the Berlin Wall was falling deep shifts were occurring in the financial systems of the developed market economies, with a greater role for securities and derivatives markets, venture capital financing followed by IPOs, and an acceleration in international financial integration to levels not seen since the end of the nineteenth century. With the spread of international finance, policies aimed at developing local stock markets in transition economies became rapidly outdated, even counterproductive. Similarly, the greater financial integration of the European Union and the world at large increased the desirability and sustainability of foreign banks in transition economies.

The ongoing globalization of the financial industry raises the issue of whether it is still meaningful to talk about national financial systems, at least for economies that are small by global standards. The remarkable presence of foreign commercial banks in the transition economies in central and eastern Europe integrates these national financial sectors into the global strategies of a small number of large financial institutions. What is the role of Hansabank and Unibanka, commercial banks active in the Baltic states, in the strategies of their Swedish parent banks? To what 


\section{William Davidson Institute Working Paper 414}

extent can we talk about domestic financial intermediation when external finance for investments come mostly from foreign savings? What influence do domestic regulators and regulation in transition economies have on the behavior of these institutions with global reach? These are some of the new questions for financial development posed by the current trends of world financial integration.

What Have We Learned?

Perhaps the main lesson of the past decade of financial transition is the importance of fiscal and monetary discipline at the critical point when the Great Divide opens up. It appears to have been a necessary condition for a successful financial transition. Without fiscal discipline, private investment is crowded out or discouraged by the looming threat of macroinstability. Lack of fiscal discipline has also been a symptom of other ills, like a lack of commitment to close down loss-making firms, poor enforcement of property rights and low tax compliance. Countries on the wrong side of the divide have been caught in a vicious circle of macro instability and repeated relapses in financial development. Financial development in these countries at best has had little effect on economic growth, and may even have been counterproductive, by making it easier for firms to receive credit and thereby reducing their incentive to undertake needed restructuring.

In the countries that have crossed the Great Divide financial 


\section{William Davidson Institute Working Paper 414}

architecture appears to have converged to a bank-based system with substantial foreign ownership. On the positive side, the financial sector in these countries has contributed to the hardening of budget constraints. However, banks have not yet begun extending significant long-term finance nor have they actively promoted restructuring in the industrial sector.

Does this mean that Lipton and Sachs (1990, 1992) have been right all along in focusing almost exclusively on issues of macro stability and in neglecting the challenge of creating the institutional foundations for a well-functioning market economy?

As we have argued throughout this article, it is not possible to consider separately the macro and micro aspects of transition. There is a basic complementarity between the macroeconomic notion of fiscal and monetary responsibility and the microeconomic foundations of sound financial institutions, protection of property rights and tax compliance. Writing new laws or transferring them more or less wholesale from abroad is a relatively easy task. Enforcement and the creation of functional institutions is much more difficult. Sound government finances create favorable conditions not only for financial development but also for proper enforcement of the law.

Conversely, financially-disciplined and tax-compliant institutions and households facilitate fiscal and monetary responsibility.

The institution of currency boards provides an instructive illustration of the complementarity of macro and micro aspects of transition. As we have pointed out several (mostly small) 


\section{William Davidson Institute Working Paper 414}

transition countries, like Bulgaria and Estonia, have adopted currency boards or equivalent arrangements fixing the exchange rate in the country's constitution. These arrangements have been reasonably effective in establishing monetary stability. But a precondition for their feasibility has been a minimum degree of microeconomic enforcement and political stability. Russia, for example, never introduced a currency board, and most economists recommended against doing so arguing that the commitment may not be sustainable given that contracts were not enforced and the financial sector was fundamentally weak. Bulgaria did introduce a currency board after severe macroeconomic instability and has achieved some moderate success, but so far the microeconomic institutions have been too weak to generate significant positive results. In the Baltics, Estonia in particular, the micro foundations were right, and the currency board arrangement has been a success.

Fiscal and monetary irresponsibility and lack of enforcement emanate from the same underlying political weaknesses. We have argued that the legitimacy of governments and their accountability to the electorate are essential preconditions. Accountability to the outside world through international agreements can also play an important role in helping governments achieve fiscal and monetary restraint. In this respect the European Union has played an important role in providing outside anchors for the financial and economic development of transition countries. The accession process has removed domestic political constraints in the 


\section{William Davidson Institute Working Paper 414}

transition countries of central and eastern Europe. The pressure to meet the criteria for EU membership was essential for the adoption and enforcement of laws and regulations, and for building the basic financial infrastructure. Perhaps even more importantly, the widely shared aspiration to "rejoin Europe" has given strong direction to, and strengthened the commitment of, the governments of these countries. Providing such anchors for the countries that have not yet succeeded in crossing the Great Divide remains a major challenge for the future. 
Table 1: Domestic credit to households and enterprises over GDP (\%)

\begin{tabular}{lccccccc}
\hline Country & 1993 & 1994 & 1995 & 1996 & 1997 & 1998 & 1999 \\
\hline Czech Rep. & & 51.8 & 55.3 & 55.5 & 60.0 & 61.5 & 56.1 \\
Estonia & 7.3 & 11.1 & 12.5 & 15.1 & 20.0 & 24.4 & 26.4 \\
Hungary & 28.7 & 24.7 & 22.3 & 20.8 & 21.4 & 22.7 & 23.4 \\
Latvia & & 14.7 & 11.8 & 7.0 & 8.5 & 12.3 & 15.7 \\
Lithuania & & 13.4 & 14.0 & 11.5 & 9.4 & 10.6 & 12.3 \\
Poland & 10.2 & 10.5 & 10.7 & 13.0 & 15.6 & 17.4 & 20.6 \\
Slovenia & & 23,1 & 27,5 & 28,8 & 28,6 & 32,8 & 35,9 \\
& & & & & & & \\
Bulgaria & 4.1 & 3.1 & 10.6 & 19.0 & 15.6 & 11.4 & 13.2 \\
Romania & & & & & 8.3 & 9.0 & 9.1 \\
Russia & & 6.8 & 7.9 & 7.0 & 7.7 & 10.6 & 10.2 \\
Slovakia & & 25.8 & 24.3 & 28.4 & 36.1 & 41.7 & 39.8 \\
Ukraine & 1.1 & 1.1 & 1.5 & 1.3 & 1.8 & 4.8 & 7.6 \\
\hline Sources: & IMF International & Financial Statistics
\end{tabular}

Table 2: EBRD Index of Banking Reform (1991-1999)

\begin{tabular}{lccccccccc}
\hline Country & 1991 & 1992 & 1993 & 1994 & 1995 & 1996 & 1997 & 1998 & 1999 \\
\hline Czech Rep. & 2 & 3 & 3 & 3 & 3 & 3 & 3 & 3 & $3+$ \\
Estonia & 1 & 2 & 3 & 3 & 3 & 3 & $3+$ & $3+$ & $4-$ \\
Hungary & 2 & 2 & 3 & 3 & 3 & 3 & 4 & 4 & 4 \\
Latvia & 1 & 2 & 2 & 3 & 3 & 3 & 3 & $2-$ & 3 \\
Lithuania & 1 & 1 & 2 & 2 & 3 & 3 & 3 & 3 & 3 \\
Poland & 2 & 2 & 3 & 3 & 3 & 3 & 3 & $3+$ & $3+$ \\
Slovenia & 1 & 2 & 3 & 3 & 3 & 3 & 3 & 3 & $3+$ \\
Bulgaria & 1 & $2-$ & 2 & 2 & 2 & 2 & $3-$ & $3-$ & $3-$ \\
Romania & 1 & 1 & 1 & 2 & 3 & 3 & $3-$ & $2+$ & $3-$ \\
Russia & 1 & 1 & 1 & 2 & 2 & 2 & $2+$ & 2 & $2-$ \\
Slovakia & 2 & $3-$ & $3-$ & $3-$ & $3-$ & $3-$ & $3-$ & $3-$ & $3-$ \\
Ukraine & 1 & 1 & 1 & 1 & 2 & 2 & 2 & 2 & 2 \\
\hline
\end{tabular}

Note: Index is in the scale from 1 to $4+.1$ stands for little progress beyond establishment of two-tier system. 4+ stands for standards and performance norms of advanced industrial economies: full convergence of banking laws and regulations with BIS standards; provision of full set of competitive banking services.

Sources: Various EBRD Transition Reports 
William Davidson Institute Working Paper 414

Table 3: EBRD Index of reforms of non-banking financial institutions (1991-1999)

\begin{tabular}{lccccccccc}
\hline Country & 1991 & 1992 & 1993 & 1994 & 1995 & 1996 & 1997 & 1998 & 1999 \\
\hline Czech Rep. & 1 & 1 & 2 & $3-$ & $3-$ & $3-$ & $3-$ & 3 & 3 \\
Estonia & 1 & 1 & $2-$ & $2-$ & $2-$ & 2 & 3 & 3 & 3 \\
Hungary & 2 & 2 & 2 & 2 & 3 & 3 & $3+$ & $3+$ & $3+$ \\
Latvia & 1 & 1 & 1 & 2 & 2 & 2 & $2+$ & $2+$ & $2+$ \\
Lithuania & 1 & 1 & $2-$ & 2 & 2 & 2 & $2+$ & $2+$ & $3-$ \\
Poland & 2 & 2 & 2 & 2 & 3 & 3 & $3+$ & $3+$ & $3+$ \\
Slovenia & 2 & 2 & 2 & $3-$ & $3-$ & $3-$ & $3-$ & $3-$ & $3-$ \\
Bulgaria & 1 & 1 & 1 & 1 & 2 & 2 & 2 & 2 & 2 \\
Romania & 1 & 1 & 1 & 2 & 2 & 2 & 2 & 2 & 2 \\
Russia & 1 & 1 & $2-$ & $2-$ & 2 & 3 & 3 & $2-$ & $2-$ \\
Slovakia & 1 & 1 & 2 & $3-$ & $3-$ & $3-$ & $2+$ & $2+$ & $2+$ \\
Ukraine & 1 & $2-$ & $2-$ & $2-$ & 2 & 2 & 2 & 2 & 2 \\
\hline
\end{tabular}

Note: Index is in the scale from 1 to $4+.1$ stands for little progress. $4+$ stands for standards and performance norms of advanced industrial economies: full convergence of securities norms and regulations with IOSCO standards; fully developed non-bank intermediation.

Sources: Various EBRD Transition Reports 
Table 4: Indicators of the Development of Banking Sector

\begin{tabular}{|c|c|c|c|c|c|c|}
\hline Country & $\begin{array}{l}\text { Concentra } \\
\text { tion }^{1}(\%, \\
1997)\end{array}$ & $\begin{array}{l}\text { Number of } \\
\text { banks } \\
(1999)\end{array}$ & $\begin{array}{c}\text { Asset share } \\
\text { of state } \\
\text { owned banks } \\
(\%, 1999)\end{array}$ & $\begin{array}{l}\text { Bad loans/ } \\
\text { total loans } \\
(\%, 1999)\end{array}$ & $\begin{array}{l}\text { Loan- } \\
\text { deposit rate } \\
\text { spread }^{2} \\
(1999)\end{array}$ & \\
\hline Czech Rep. & 74,9 & 42 & 23,2 & 31,4 & 4,2 & \\
\hline Estonia & 84,5 & 7 & 7,9 & 3,1 & 4,5 & \\
\hline Hungary & 67,4 & 39 & 9,1 & 2,8 & 3,4 & \\
\hline Latvia & 53,1 & 23 & $8.5^{4}$ & $6.3^{4}$ & 9,2 & \\
\hline Lithuania & 69,7 & 13 & 41,9 & 11,9 & 8,2 & \\
\hline Poland & 42,3 & 77 & 25.0 & 14,5 & 5,8 & \\
\hline Slovenia & 71,7 & 31 & 41,7 & 10,2 & 5,1 & \\
\hline Bulgaria & 86,7 & $28^{3}$ & $66^{3}$ & $12.9^{3}$ & 9,6 & \\
\hline Romania & 85,0 & 34 & 50,3 & 36,6 & & \\
\hline Russia & 53,7 & 2376 & $41.9^{4}$ & 13,1 & 26,0 & \\
\hline Slovakia & 84,5 & 25 & 50,7 & 40.0 & 6,7 & \\
\hline Ukraine & 64,4 & 161 & 12,5 & 3,3 & 34,3 & \\
\hline \multicolumn{7}{|c|}{$\begin{array}{l}\text { Notes: } \\
1 \text { - Defined as the ratio of three largest banks' assets to total banking } \\
\text { sector assets. } \\
2 \text { - Loan rate is defined as the average rate charged by commercial banks on } \\
\text { outstanding short term credits to enterprises and individuals, weighted by } \\
\text { loan amounts. Weighted average of credits of all maturity is used for Czech } \\
\text { Rep., Lithuania and Ukraine. For Poland only minimum risk loans are } \\
\text { considered. Deposit rate is defined as the average rate offered by commercial } \\
\text { banks on short term deposits, weighted by deposit amounts. Weighted average of } \\
\text { deposits of all maturity is used for Czech Rep., Estonia, Lithuania and } \\
\text { Ukraine. } \\
3 \text {-Data for } 1997 \text {. } \\
4 \text {-Data for } 1998 \text {. }\end{array}$} \\
\hline
\end{tabular}

Sources: IMF International Financial Statistics, IMF Staff Country report Nr.00/59, WB Database on Financial Development and Structure, EBRD Transition Report 2000 
William Davidson Institute Working Paper 414

Table 5: Number of companies listed on the stock market

\begin{tabular}{lrrrrrrr}
\hline \multicolumn{1}{c}{ Country } & 1994 & 1995 & 1996 & 1997 & 1998 & 1999 & $\begin{array}{r}2000 \\
\text { (March) }\end{array}$ \\
\hline Czech Rep. & 1024 & 1635 & 1588 & 276 & 261 & 164 & 154 \\
Estonia & 0 & 0 & 0 & 22 & 26 & 25 & 23 \\
Hungary & 40 & 42 & 45 & 49 & 55 & 66 & 65 \\
Latvia & 0 & 17 & 34 & 50 & 69 & 70 & 64 \\
Lithuania & 13 & 357 & 460 & 607 & 60 & 54 & 54 \\
Poland & 44 & 65 & 83 & 143 & 198 & 221 & 221 \\
Slovenia & 25 & 17 & 21 & 26 & 28 & 28 & 34 \\
& & & & & & & \\
Bulgaria & 16 & 26 & 15 & 15 & 998 & 828 & 842 \\
Romania & 4 & 7 & 17 & 76 & 5753 & 5825 & 5578 \\
Russia & 72 & 170 & 73 & 208 & 237 & 207 & 218 \\
Slovakia & 19 & 21 & 816 & 872 & 837 & 845 & 843 \\
Ukraine & 0 & 96 & 99 & 102 & 113 & 117 & 120 \\
\hline
\end{tabular}

Sources: Emerging Markets Fact book, International Finance Corporation,

Claessens, S., S. Djankov and D. Klingebiel, 2000, "Stock Markets in Transition Economies," The World Bank, Financial Sector Discussion Paper 5. 


\section{Figure 1: Gini coefficients for selected transition economies}

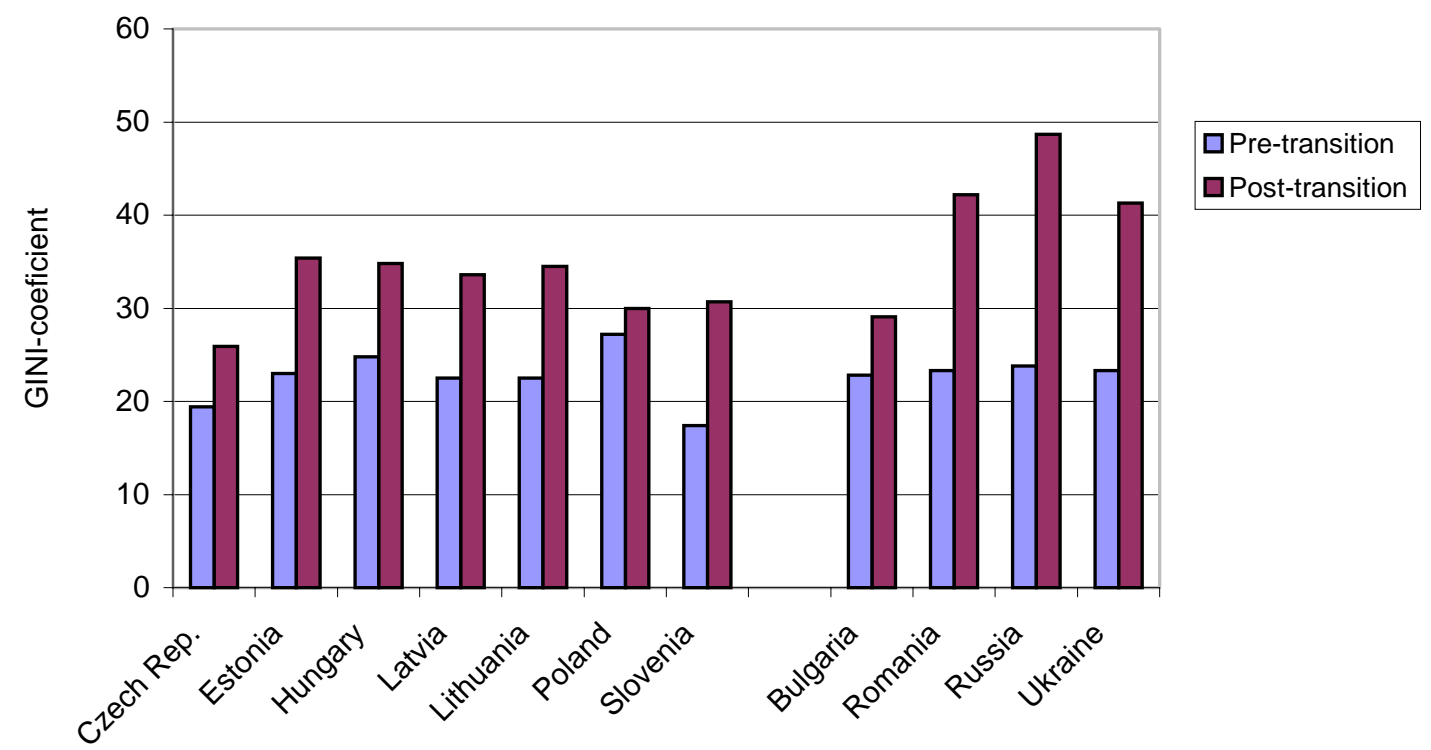

Note: Pre-transition data taken from Keane, M., and E. Prasad, "Inequalities, Transfers and Growth: New Evidence from the Economic Transition in Poland," IMF Working Paper 00/177, June 2000. Posttransition data refers to 1997, except for Russia - 1998, Ukraine - 1996, Bulgaria - 1996 and Estonia 1995.

Sources: EBRD Transition Report 2000, World Bank World Development Indicators 2000, Keane, M., and E. Prasad, "Inequalities, Transfers and Growth: New Evidence from the Economic Transition in Poland," IMF Working Paper 00/177, June 2000. 


\section{William Davidson Institute Working Paper 414}

Acknowledgements

We are grateful to Philippe Aghion, Mike Burkart, Stijn
Claessen, Tore Ellingsen and, in particular, Enrico Perotti for
helpful discussions; to Jan Hanousek and participants in the
Journal of Economic Perspectives workshop at CERGE-EI, Prague, the
Czech Republic; and to colleagues at SITE at the Stockholm School
of Economics for comments. Rudolf Bems has provided excellent
research assistance.




\section{William Davidson Institute Working Paper 414}

References

Abel, I. and J. Bonin, 2000, "Retail Banking in Hungary: A Foreign Affair," William Davidson Institute Working Paper 356.

Acemoglu, D., S. Johnson and J. Robinson, 2000, "The Colonial Origins of Comparative Development: An Empirical Investigation," mimeo, MIT.

Beck, T., A. Demirguc-Kunt and R. Levine 2001, "Law, Politics, and Finance," mimeo, World Bank.

Benabou R., 1996, "Inequality and Growth", NBER Macroeconomics Annual, Cambridge.

Berglof E., and Roland G., 1998, "Soft Budget Constraints and Banking in Transition Economies," Journal of Comparative Economics, 26, 1: 18-40.

Berglof E., and Roland G., 2002, "From Regatta to Big Bang - The Political Economy of Accession to the European Union," IMF Working Paper, forthcoming.

Berliner, J., 1976, The Innovation Decision in Soviet Industry. MIT Press. 


\section{William Davidson Institute Working Paper 414}

Bortolotti B., M. Fantini and D. Siniscalco, 2001, "Privatization: Politics, Institutions and Financial Markets", FEEM discussion paper

Burnside, C., M. Eichenbaum and S. Rebelo, 2001, "Prospective Deficits and the Asian Currency Crisis", Journal of Political Economy, forthcoming.

Calvo, G., and F. Coricelli, 1995, "Inter-enterprise Arrears in Economies in Transition" in Output decline in Eastern Europe: Unavoidable, external influence or homemade?, International Studies in Economics and Econometrics, vol. 34. Dordrecht; Boston and London: Kluwer Academic, 193-212.

Claessens, S., S. Djankov and D. Klingebiel, 2000, "Stock Markets in Transition Economies," The World Bank, Financial Sector Discussion Paper 5.

Djankov, S., and P. Murrell, 2000, "Enterprise Restructuring in Transition: A Quantitative Survey"

EBRD, 1998 and 2000, Transition Report.

Fries, S., and A. Taci, 2001, "Banking Reform and Development in Transition Economies," mimeo, European Bank of Reconstruction and 


\section{William Davidson Institute Working Paper 414}

Development .

Gerschenkron, A., 1962, Economic Backwardness in Historical Perspective, A Book of Essays, Harvard University Press, Cambridge.

Hellman, J., G. Jones, and D. Kaufmann, 2000 "Seize the State, Seize the Day state Capture, Corruption, and Influence in Transition," World Bank Working Paper \#2444.

Kaufmann, D., Hellman, J., G. Jones, and M. Schankerman, 2000 "Measuring Governance, Corruption, and State Capture: How Firms and Bureaucrats Shape the Business Environment in Transit", World Bank Working Paper \#2312.

Haizhou Huang, Marin, Dalia and Chenggang Xu, 2001 "Financial Crisis, Economic Recovery and Banking Development in Russia", mimeo, Munich University

IMF, 2000, World Economic Outlook, Ch. 4.

Johnson, S., P. Boone, A. Breach, and E. Friedman, 1998, "Corporate Governance in the Asian Financial Crisis 1997-98," Stockholm Institute of Transition Economics Working Paper No 137.

Johnson, S., McMillan J., Woodruff C. 1999, "Contract enforcement 


\section{William Davidson Institute Working Paper 414}

in transition", EBRD Working Paper 45, London.

King, R. and R. Levine, 1993a, "Finance, Entrepreneurship, and Growth: Theory and Evidence", Journal of Monetary Economics, December 1993, v. 32, iss. 3, pp. 513-42.

King, R. and R. Levine, 1993b, "Finance and Growth: Schumpeter Might be Right", Quarterly Journal of Economics, 108, 717-38.

Kornai, J., 1992, The Socialist System: The Political Economy of Communism. Oxford University Press, Oxford.

Laporta, R., F. Lopez-de-Silanes, A. Shleifer and R. Vishny, 1997, "Legal Determinants of External Finance", Journal of Finance 52, $1131-1150$.

LaPorta, R., F. Lopez-de-Silanes, A. Shleifer and R. Vishny, 1998, "Law and Finance", Journal of Political Economy 106, 1113-1155.

Laporta, R., F. Lopez-de-Silanes, A. Shleifer and R. Vishny, 1999, "Corporate Ownership Around the World", Journal of Finance 54, $471-517$.

Levine, R., 2000, "Bank-Based or Market-Based Financial Systems: Which is Better?" mimeo, University of Minnesota. 


\section{William Davidson Institute Working Paper 414}

Levine, R. and S. Zervos, 1998, "Stock Markets, Banks, and Economic Growth," American Economic Review, June 1998, v. 88, iss. 3, pp. 537-58.

Levine, R., N. Loayza and T. Beck 2000, "Financial Intermediary Development and Growth: Causes and Causality," Journal of Monetary Economics, 2000, 46(1): 31-77.

Lipton, D. and J. Sachs, 1990, "Creating A Market Economy in Eastern Europe: The Case of Poland," Brookings Papers of Economic Activity, 2:293-333.

1992, "Prospects for Russian Economic Reforms," Brookings Papers of Economic Activity, 2: 213-265.

Mitchell, J. 1998, "The Problem of Bad Debts: Clearing Banks' Balance Sheets in Economies in Transition". CEPR Discussion Papers. No. 1977. London:CEPR.

Olson, M., 1982, The Rise and Decline of Nations, Yale University Press.

Padilla, A.J. and A. Requejo, 2000, "The Costs and Benefits of the strict protection of Creditor Rights: Theory and Evidence". IADB Discussion Paper No. R-384 


\section{William Davidson Institute Working Paper 414}

Pagano, M., 1993, "Financial Markets and Growth: An Overview", European Economic Review, 37, 613-622

Perotti, E., 1998, "Inertial Credit and Opportunistic Arrears in Transition," European Economic Review, 42: 1703-1725

Perotti, E and S. Gelfer, 2001, "Red Barons or Robber Barons ? Governance and Financing in Russian Financial-Industrial Groups", European Economic Review, forthcoming.

Perotti, R., 1996, "Growth, Income Distribution and Democracy: What the Data say", Journal of Economic Growth, 1: 149-188

Pistor, K. 2000, "Patterns of legal change: shareholder and creditor rights in transition economies," EBRD Working Paper, 49, London

Pistor, K., M. Raiser and S. Gelfer, 2000, "Law and Finance in Transition", Economics of Transition, 8, 2: 325-368

Qian, Y., and C. Xu, 1993, "Why China's Economic Reform Differ," Economics of Transition, 1:2, 135-170.

Rajan, R. and L. Zingales, 1998, "Finance Dependence and Growth," American Economic Review 88, 559-29. 


\section{William Davidson Institute Working Paper 414}

Rajan, R., and L. Zingales, 2000, "The Great Reversal," NBER discussion paper No. 8178 .

Sgard, J., 1996, "Banks during Transition: What have we learned?", mimeo, CEPII.

Tadasse, S., 2000, "Financial Architecture and Economic Performance: International Evidence", mimeo University of South Carolina

Helena Tang, Edda Zoli and Irina Klytchnikova, 2000, "Banking Crises in Transition economies: fiscal costs and related issues," World Bank Policy Research Working Paper, No. 2484, November.

Volchkova, N., 2000, Does Financial-Industrial Group Membership Affect Fixed Investment: Evidence from Russia, CEFIR Working Paper No 4

Walsh, P., and F. Duffy, 2000, "Individual Pay and Outside Options: Evidence from the Polish Labour Force Survey", William Davidson Institute Working Paper No 364 . 


\section{DAVIDSON INSTITUTE WORKING PAPER SERIES - Most Recent Papers}

The entire Working Paper Series may be downloaded free of charge at: www.wdi.bus.umich.edu

CURRENT AS OF 12/13/01

\begin{tabular}{|c|c|c|}
\hline Publication & Authors & Date \\
\hline $\begin{array}{l}\text { No. } 414 \text { Forthcoming in: The Journal of Economic Perspectives, "The } \\
\text { Great Divide and Beyond: Financial Architecture in Transition." }\end{array}$ & Erik Berglof and Patrick Bolton & Dec. 2001 \\
\hline $\begin{array}{l}\text { No. } 413 \text { Forthcoming in: The Journal of Economic Perspectives, "The } \\
\text { Political Economy of Transition." }\end{array}$ & Gérard Roland & Dec. 2001 \\
\hline $\begin{array}{l}\text { No. 412: The Response of Consumption in Russian Households to } \\
\text { Economic Shocks }\end{array}$ & Steven Stillman & Oct. 2001 \\
\hline No. 411: Mark-ups in Hungarian Corporate Sector & László Halpern and Gábor Körösi & Aug. 2001 \\
\hline No. 410: Economic Development, Legality, and the Transplant Effect & $\begin{array}{l}\text { Daniel Berkowitz, Katarina } \\
\text { Pistor, Jean-Francois Richard }\end{array}$ & Sept. 2001 \\
\hline No. 409: Development Strategy, Viability, and Economic Convergence & Justin Yifu Lin & Oct. 2001 \\
\hline No. 408: Labor Supply, Informal Economy and Russian Transition & Maxim Bouev & May 2001 \\
\hline No. 407: Corporate Governance in China: Then and Now & Cindy Schipani and Liu Junhai & Nov. 2001 \\
\hline No. 406: Entrepreneurship and Post-Socialist Growth & $\begin{array}{l}\text { Daniel Berkowitz and David N. } \\
\text { DeJong }\end{array}$ & Oct. 2001 \\
\hline $\begin{array}{l}\text { No. } 405 \text { Forthcoming in: European Economic Review, "Policy Reform } \\
\text { and Growth in Post-Soviet Russia." }\end{array}$ & $\begin{array}{l}\text { Daniel Berkowitz and David N. } \\
\text { DeJong }\end{array}$ & Oct. 2001 \\
\hline $\begin{array}{l}\text { No. 404: Social Policies and Structures: Institutional Frictions and Traps } \\
\text { in the Czech Republic after } 1989\end{array}$ & Jiří Večerník & Nov. 2001 \\
\hline $\begin{array}{l}\text { No. 403: Investment, Efficiency, and Credit Rationing: Evidence from } \\
\text { Hungarian Panel Data }\end{array}$ & Mathilde Maurel & Nov. 2001 \\
\hline $\begin{array}{l}\text { No. 402: Subduing High Inflation in Romania. How to Better Monetary } \\
\text { and Exchange Rate Mechanisms? }\end{array}$ & $\begin{array}{l}\text { Daniel Daianu and Radu } \\
\text { Vranceanu }\end{array}$ & Aug. 2001 \\
\hline $\begin{array}{l}\text { No. 401: The Gender Wage Gap in Bulgaria: A Semiparametric } \\
\text { Estimation of Discrimination }\end{array}$ & Dean Jolliffe & July 2001 \\
\hline $\begin{array}{l}\text { No. 400: Do External Auditors Perform a Corporate Governance Role in } \\
\text { Emerging Markets? Evidence from East Asia }\end{array}$ & Joseph P. H. Fan and T.J. Wong & Oct. 2001 \\
\hline $\begin{array}{l}\text { No. 399: Financial Conditions and Investment during the Transition: } \\
\text { Evidence from Czech Firms }\end{array}$ & Lubomír Lízal and Jan Svejnar & Oct. 2001 \\
\hline $\begin{array}{l}\text { No. 398: Accessible Pareto-Improvements: Using Market Information to } \\
\text { Reform Inefficiencies }\end{array}$ & Michael Mandler & May 2001 \\
\hline No. 397: The Making of an Integrated National Grain Market in China & Wubiao Zhou & Oct. 2001 \\
\hline No. 396: Corruption and Resource Allocation: Evidence from China & Wei Li & June 2001 \\
\hline $\begin{array}{l}\text { No. 395: Government Shareholding and the Value of China's Modern } \\
\text { Firms }\end{array}$ & Lihui Tian & Apr. 2001 \\
\hline No. 394: Labor Hoarding in Russia: Where Does it Come from? & $\begin{array}{l}\text { Rouslan Koumakhov and Boris } \\
\text { Najman }\end{array}$ & June 2000 \\
\hline $\begin{array}{l}\text { No. 393: Ownership Structure, Corporate Governance, And Firm Value: } \\
\text { Evidence from the East Asian Financial Crisis }\end{array}$ & Michael Lemmon and Karl Lins & Apr. 2001 \\
\hline No. 392: Marshall and Labour Demand in Russia: Going Back to Basics & $\begin{array}{l}\text { Jozef Konings and Hartmut } \\
\text { Lehmann }\end{array}$ & Aug. 2001 \\
\hline No. 391: Economic Transition and Elections in Poland & $\begin{array}{l}\text { John E. Jackson, Jacek Klich, and } \\
\text { Krystyna Poznańska }\end{array}$ & June 2001 \\
\hline $\begin{array}{l}\text { No. 390: Effects of Bank Insolvency and Strategic Uncertainty on } \\
\text { Corporate Restructuring in Transition Economies }\end{array}$ & Christa Hainz & Aug. 2001 \\
\hline No. 389: Mark-Up Pricing In Bulgarian Manufacturing & $\begin{array}{l}\text { Rumen Dobrinsky, Boyko } \\
\text { Nikolov, and Nikolay Markov }\end{array}$ & June 2001 \\
\hline $\begin{array}{l}\text { No. 388: Globalization and Firms' Financing Choices: } \\
\text { Evidence from Emerging Economies }\end{array}$ & $\begin{array}{l}\text { Sergio Schmukler and Esteban } \\
\text { Vesperoni }\end{array}$ & May 2001 \\
\hline
\end{tabular}

